\title{
The Difference of Cost of Good Manufactured Determination Using Traditional and Activity-Based Costing Method
}

\author{
Ida Farida Adi Prawira ${ }^{1},{ }^{2}$ Anis Paskalia Sariningsih ${ }^{2}$, Muhamad Naufal ${ }^{3}$ \\ Program Studi Akuntansi, Fakultas Pendidikan Ekonomi dan Bisnis, Universitas Pendidikan Indonesia, Bandung, Indonesia ${ }^{1}$ \\ Program Studi Akuntansi, Fakultas Pendidikan Ekonomi dan Bisnis, Universitas Pendidikan Indonesia, Bandung, Indonesia ${ }^{2}$ \\ Program Studi Akuntansi, Fakultas Pendidikan Ekonomi dan Bisnis, Universitas Pendidikan Indonesia, Bandung, Indonesia ${ }^{3}$
}

\begin{abstract}
This research's goal is to know the difference in the cost of good manufactured determination using traditional and activity-based costing in an MSMEs. This research can be classified into descriptive qualitative research with case study research design. The data in this research are collected by the triangulation method and the data is analyzed by data reduction, data display, and verification. The calculation of cost of good manufactured using Activity-Based Costing shows the average margin percentage is higher compared to the usage of traditional method. Activity-Based Costing Method can allocate the cost to the activities accurately dan help the management to determine the selling price.
\end{abstract}

Keywords: Activity Based Costing; Traditional Method; Production Cost; Cost of Good Manufactured; Selling Price.

Corresponding author. E-mail address: ida.farida@upi.edu

Received December 2018; Received in revised February 2019; Accepted May 2019

International Journal Management \& Busines Vol 1, No 1 (2019) 41-46

\section{Introduction}

This globalization era makes the industry more competitive, so the challenge for the MSMEs is the obligation to build a strong foundation for their business. The MSMEs have to increase their productivity and expand the market by maintaining the market position. The market position can be maintained if the company able to supply on time and with a competitive price. The product price can be competitive if the direct material, direct labor, and factory overhead cost are traced, calculated, and expensed accurately (Surya, 2013). Products that manufactured by the company will be more variative. The usage of general average to standardizing the distribution of resource costs for different products can result in inaccurate and misleading product costs. (Horngren, 2010, p. 160). This is due to the different consumption costs for each product. To increase sales due to increased demand, companies need to know the real cost of the previous section to decide which items will be reproduced or produced more (Nitin Kumar, 2013).

The company can set the selling price appropriately if it can calculate the cost of good manufactured accurately. The inaccuracy in the calculation of cost of good manufactured causes harmful effects to the company, because the cost of good manufactured serves as the basis for setting the selling price and the profit, as a tool to measure the efficiency of the production process and as a basis for decision making for the company's management (Rahmaji, 2013). 
Generally, companies use the traditional method for determining the cost of good manufactured, but this method has several disadvantages, including the existence of costs that do not have a direct relationship with the manufacture of the products included in the calculation of overhead costs, the existence of costs associated with the process of making products that are not fair, and the diversification of products which are costed by the same overhead costs even though the activities are different. (Mursyidi, 2010, p. 285).

Therefore, we need an appropriate financing method, namely Activity Based Costing, a method that was first introduced in the United States during the 1980s by Cooper and Kaplan. Activity Based Costing System plays a role in measuring and evaluating the level of achievement of company profitability, because it has a better level of accuracy (Tandiontong \& Lestari, 2011). But Zongshengs (2010) in his research stated that, due to different characteristics, small and medium enterprises must develop their own financial management strategies instead of copying from large companies. With the differences of opinion of the experts, the researchers were interested in conducting this research. The purpose of this study was to determine the differences in the cost of good manufactured with Traditional Methods and Activity Based Costing Methods.

\section{Literature Review}

The company can set the selling price appropriately if it can calculate the Cost of Production accurately. Garrison et al. (2013, p. 104 ) says that the Cost of Production is the cost of a product related to goods that are completed in a certain period. There are three elements in calculating Cost of Production, namely direct materials, direct labor, and overhead costs (Horngren, 2010, p. 43).
According to Mursyidi (2010, p. 285), the calculation of basic prices that developed in the industrial world can be classified into two groups, namely the calculation of conventional or traditional cost prices where factory overhead costs are determined in advance based on a plant-wide system and calculation of cost based on activity (Activity-Based Costing / $A B C$ ), where factory overhead or conversion costs are charged based on pre-determined rates related to production activities. Carter (2009, p. 499) says that traditional cost methods have special characteristics, namely the use of measures related to volume or size exclusively as a basis for allocating overhead to output. For these reasons, the traditional cost method is also called the unit-based method (Unit Cost Method). According to Horngren (2010, p. 161), cost smoothing can cause the calculation of the cost of a product or service that is too low (undercosting) or too high (overcosting).

Allocation by using a unit basis can cause a distortion of cost of goods sold because the product does not consume costs which is proportional to the volume of production (Adie, 2011). Hamdallah Mahder (2014) says that traditional cost-based methods are not possible to provide accurate cost information to help with pricing and decision making, for which $A B C$ is a valuable management support tool for small manufacturing companies. According to Horngren et al. (2010, pp. 167-168), the ABC method improves the cost calculation method by identifying individual activities as the object of fundamental costs. $A B C$ method calculates the cost of each activity and imposes costs on cost objects such as products and services based on the activities needed to produce each product or service. 
To perform cost calculations, there are four cost hierarchies that categorize indirect costs into different cost pools based on the type of cost trigger. The hierarchy consists of unit level costs, batch level costs, product support costs, and facility support costs (Horngren, 2010 , p. 171). According to Hansen Mowen (2013, pp. 153-167) the first stage in determining the Cost of Production with Activity Based Costing Method is to classify various activities, associate various costs with various activities, determine the right cost driver, determine homogeneous cost groups, and determine rates group, then the second stage is the cost for each group traced to various types of products using group rates consumed by each product.

\section{Research Method}

This research is a qualitative descriptive study with a case study research design. The research participant was MSMEs of candle maker in Bandung, namely CV Anugrah Jaya Indonesia. Data collection is done by triangulation technique. Primary data is obtained directly through interviews and documentation study from CV Anugrah Jaya Indonesia. The type of data needed is qualitative and quantitative data. Included in the qualitative data are the history of the company, the location of the company, the marketing area, and the method of production, while the qualitative data are production data in 2016, data on raw material usage in 2016, direct labor cost data for 2016, and factory overhead data for 2016. Data analysis is done by reducing data, displaying data, and drawing conclusions. The steps taken in data analysis are data collection through research instruments, obtaining detailed cost data in 2016, reducing the data needed to calculate Cost of Production, calculating Cost of Production with Activity Based Costing, comparing and analyzing calculation results with Traditional Methods and Methods Activity Based Costing, and finally get the results of the study.

\section{Discussion And Result}

Description of the Results of Comparison of Traditional Methods and Activity Based Costing Methods. The difference in the determination of the Cost of Production with Traditional Methods and the Activity Based Costing Method is presented in table 1

Table 1. Cost of Good Manufactured Comparison between Traditional Method and Activity Based Costing Method

\begin{tabular}{|c|c|c|c|c|c|c|c|c|c|}
\hline \multirow{2}{*}{$\begin{array}{l}\begin{array}{c}\text { Product } \\
\text { Type }\end{array} \\
\text { JB20 }\end{array}$} & \multicolumn{2}{|c|}{$\begin{array}{c}\text { Traditional } \\
\text { Method }\end{array}$} & \multicolumn{2}{|c|}{ ABC Method } & \multicolumn{2}{|c|}{ Difference } & \multirow{2}{*}{$\begin{array}{l}\text { Condition } \\
\text { Undercosted }\end{array}$} & \multirow{2}{*}{$\begin{array}{c}\begin{array}{c}\text { Traditional } \\
\text { Method } \\
\text { Margin (\%) }\end{array} \\
28\end{array}$} & \multirow{2}{*}{$\begin{array}{c}A B C \\
\text { Method } \\
\text { Margin } \\
(\%) \\
26 \\
\end{array}$} \\
\hline & $\mathrm{Rp}$ & 97.528 & $\mathrm{Rp}$ & 99.165 & $\mathrm{Rp}$ & (1.637) & & & \\
\hline JM20 & $\mathrm{Rp}$ & 107.022 & $\mathrm{Rp}$ & 108.588 & $\mathrm{Rp}$ & $(1.566)$ & Undercosted & 35 & 34 \\
\hline KCL60 & $\mathrm{Rp}$ & 133.299 & $\mathrm{Rp}$ & 132.246 & $\mathrm{Rp}$ & 1.053 & Overcosted & 24 & 25 \\
\hline KCL60.P & $\mathrm{Rp}$ & 132.935 & $\mathrm{Rp}$ & 113.309 & $\mathrm{Rp}$ & 19.626 & Overcosted & 14 & 33 \\
\hline TG40 & $\mathrm{Rp}$ & 134.206 & $\mathrm{Rp}$ & 134.194 & $\mathrm{Rp}$ & 12 & Overcosted & 30 & 30 \\
\hline TG40.P & $\mathrm{Rp}$ & 134.161 & $\mathrm{Rp}$ & 124.556 & $\mathrm{Rp}$ & 9.605 & Overcosted & 23 & 32 \\
\hline
\end{tabular}




\begin{tabular}{|c|c|c|c|c|c|c|c|}
\hline $\begin{array}{l}\text { Product } \\
\text { Type }\end{array}$ & $\begin{array}{c}\text { Traditional } \\
\text { Method }\end{array}$ & ABC Method & & ference & Condition & $\begin{array}{l}\text { Traditional } \\
\text { Method } \\
\text { Margin (\%) }\end{array}$ & $\begin{array}{c}\text { ABC } \\
\text { Method } \\
\text { Margin } \\
(\%)\end{array}$ \\
\hline TGK.P & Rp 124.969 & Rp 122.401 & $\mathrm{Rp}$ & 2.568 & Overcosted & 24 & 27 \\
\hline VC20 & Rp $\quad 75.708$ & Rp 77.998 & $\mathrm{Rp}$ & (2.289) & Undercosted & 39 & 35 \\
\hline VC20.P & 76.208 & 71.230 & $\mathrm{Rp}$ & 4.978 & Overcosted & 33 & 42 \\
\hline Rata-rata & & & & & & 28 & 32 \\
\hline
\end{tabular}

Source: CV Anugrah Jaya Indonesia (processed data)

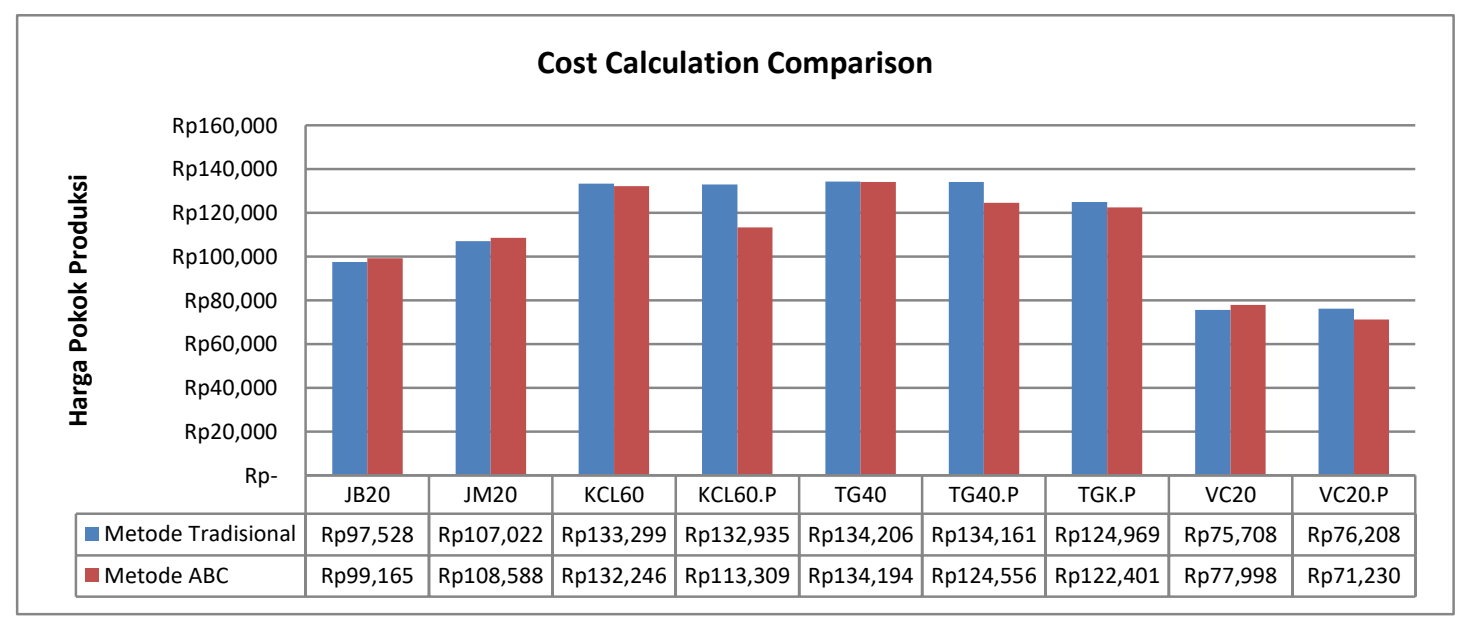

Figure 1 Comparative Diagram of Cost of Production with Traditional Methods and Activity Based Costing Methods

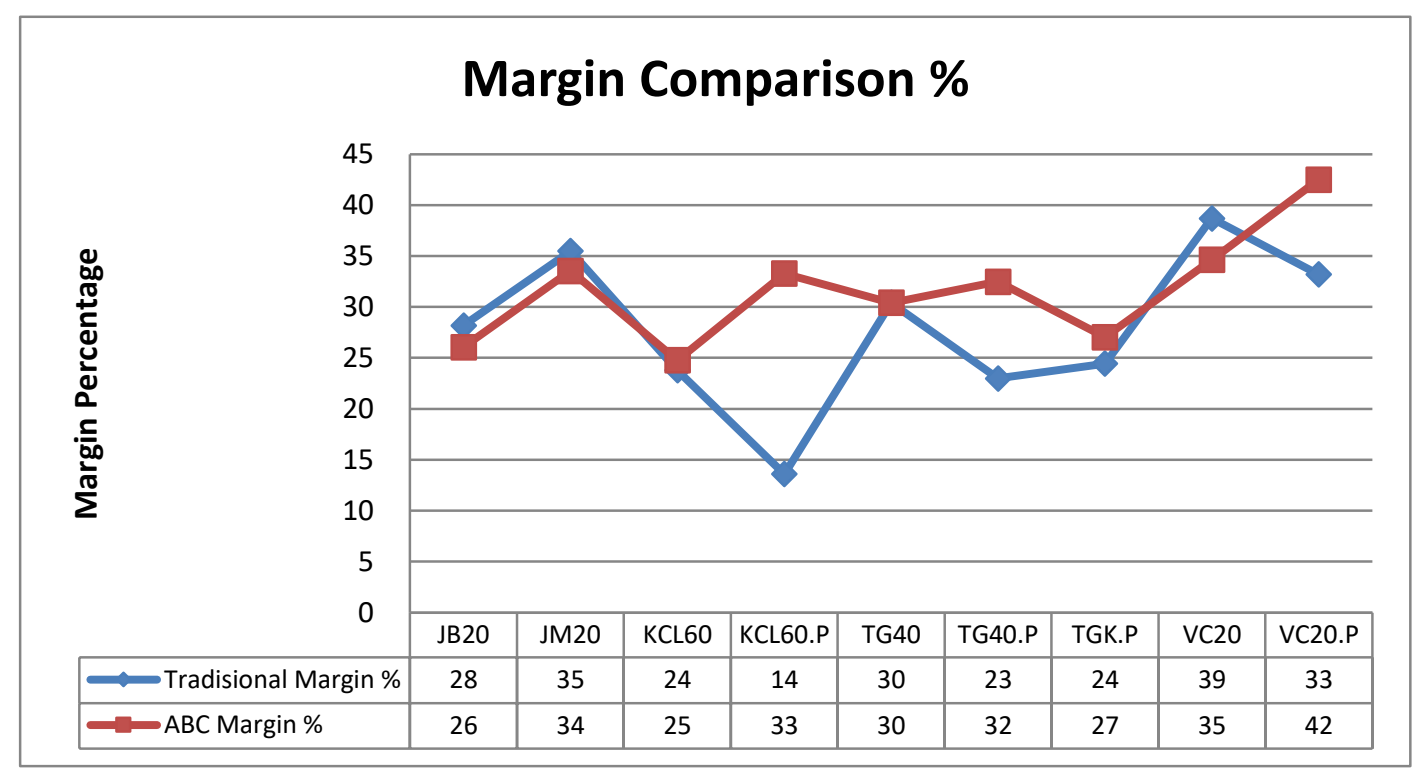

Figure 1 Comparison Chart of the Cost of Production with Traditional Methods and Activity Based Costing Method

Ida Farida Adi Prawira ${ }^{1}$, Anis Paskalia Sariningsih ${ }^{2}$, Muhamad Naufal ${ }^{3}$ - The Difference of 
Based on the table above, it can be seen the comparison of the calculation results of Cost of Production with Traditional Methods and Activity Based Costing Method. Activity Based Costing method gives greater results for JB20, JM20, and VC20 type products, while for KCL60 type products, KCL60 type. P, TG40 type, TG40.P type, and VC20 type. $P$ shows smaller results. The difference for JB20 is Rp1,637, for JM20 is Rp1,566, for KCL60 is Rp1,053, for KCL60.P is Rp.19,626, for TG40 is Rp.12, for TG40.P is Rp.9,605, for TGK.P amounting to Rp2,568, for VC20 of Rp.2,289, and for VC20.P of Rp.4,978.

This difference is caused by the imposition of Factory Overhead Costs on each product between Traditional Methods and different Activity Based Costing Methods. In the Traditional Method, the Cost Driver is only the number of units as a Factory Overhead Cost, as in the Activity Based Costing Method, to charge the Factory Overhead Cost using the number of units, number of cartons, number of packs, and area as the Cost Driver. Calculation of Cost of Production by using Activity Based Costing Method allocates costs to products according to the activities they consume, thus giving more precise results.

\section{Conclusion}

Based on the results of research and discussion about the differences in the Cost of Production by using the Traditional Method and Activity Based Costing Method, it can be concluded that the calculation of Cost of Production using Activity Based Costing method results in a higher average percentage margin compared to the Traditional Method. Cost of Production Calculation by using Activity Based Costing Method allocates costs to products according to the activities they consume, thus providing more precise results and does not cause cost distortions, besides it can help management in making decisions to determine selling prices.

The limitations of this study are that research is only conducted on one company, it is expected that the next researcher will conduct research with more diverse research objects, or can choose service companies, such as hospitals, hotels, consultants, and also trading companies. In addition, other methods can also be used in determining the Cost of Production, such as Job Order Costing.

\section{References}

Adie, A. F. (2011). Peranan Activity-based Costing System dalam Perhitungan Harga Pokok Produksi Kain yang Sebenarnya untuk Penetapan Harga Jual (Studi Kasus pada PT Panca Mitra Sandang Indah). Jurnal IImiah Akuntansi.

Hamdallah Mahder E, O. S. (2014). Using Costing Systems in order to Price Products in Small Textile, Leather, and Clothing Companies: Field Study from Jordan. International Review of Management and Business Research, 3(1), 113-118.

Hansen/Mowen. (2013). Akuntansi Manajerial. Jakarta: Salemba Empat.

Horngren, C. T., Datar, S. M., \& Foster, G. (2010). Akuntansi Biaya dengan Penekanan Manajerial. Jakarta: Erlangga

Mursyidi. (2010). Akuntansi Biaya Conventional Costing, Just In Time, dan Activity Based Costing. Bandung: PT Refika Aditama.

Nitin Kumar, D. M. (2013). A Comparative Analysis and Implementation of Activity Based Costing $(\mathrm{ABC})$ and Traditional Cost Accounting (TCA) Methods in an 
Automobile Parts Manufacturing Company: A Case. Global Journal of Management and Business Research, 13(4), 29-38.

Rahmaji, D. (2013). Penerapan Activity-Based Costing System Untuk Menentukan Harga Pokok Produksi Pt. Celebes Mina Pratama. Jurnal EMBA, 1(3), pp. 63-73.

Ray H. Garrison, E. W. (2013). Akuntansi Manajerial. Jakarta: Salemba Empat.

Surya, R. T. (2013, Januari). Pengembangan Model Analisis dan Implementasi Activity-Based Costing ( $A B C$ ) untuk Meningkatkan Daya Saing UMKM. Dipetik Desember 5, 2016, dari http://www.kompasiana.com/rendratr is/pengembangan-model-analisis-danimplementasi-activity-based-costingabc-untuk-meningkatkan-daya-saingumkm_551b64aa8133117e089de781

Tandiontong, M., \& Lestari, A. (2011). Peranan Activity-Based Costing System Dalam Perhitungan Harga Pokok Terhadap Peningkatan Profitabilitas Perusahaan (Studi Kasus pada PT Retno Muda Pelumas Prima Tegal). Jurnal IImiah Akuntansi(6), pp. 1-23. 